\title{
Nasal Cavity and Ethmoid Sinus Cancer Pathologic Regional Lymph Nodes TNM Finding v6
}

National Cancer Institute

\section{Source}

National Cancer Institute. Nasal Cavity and Ethmoid Sinus Cancer Pathologic Regional Lymph Nodes TNM Finding v6. NCI Thesaurus. Code C65035.

A pathologic finding about one or more characteristics of nasal cavity and ethmoid sinus cancer, following the rules of the TNM AJCC v6 classification system as they pertain to staging of regional lymph nodes. 